\title{
The effects of GH-releasing hormone/somatostatin on the 5'-promoter activity of the GH gene in vitro
}

\author{
M Morishita, Y Iwasaki ${ }^{1}$, A Onishi, M Asai, N Mutsuga, M Yoshida, Y Oiso, \\ $\mathrm{K}$ Inoue ${ }^{2}$ and $\mathbf{T}$ Murohara \\ Department of Medicine, Nagoya University Graduate School of Medicine and Hospital, Nagoya 466-8550, Japan \\ ${ }^{1}$ Department of Clinical Pathophysiology, Nagoya University Graduate School of Medicine and Hospital, Nagoya 466-8550, Japan \\ ${ }^{2}$ Department of Cell Regulation, Saitama University, Saitama 338-0825, Japan
}

(Requests for offprints should be addressed to Y Iwasaki, Department of Clinical Pathophysiology, Nagoya University Graduate School of Medicine and Hospital, 65 Tsurumai-cho, Showa-ku, Nagoya 466-8550, Japan; Email: iwasakiy @med.nagoya-u.ac.jp)

\begin{abstract}
The two hypothalamic hormones, GH-releasing hormone (GHRH) and somatostatin (SRIF), are known to regulate $\mathrm{GH}$ secretion. However, the effects of these hormones on $\mathrm{GH}$ gene expression are not completely clear, partly because of the lack of appropriate host cells maintaining the original characteristics of the somatotroph. Since MtT/S, a pure somatotroph cell line, has become available, the effects of GHRH and SRIF on GH gene transcription have been studied using a subclone of MtT/S (MtT/SGL), in which the GH gene 5'-promoter-luciferase fusion gene was stably incorporated. The expression of GHRH receptor and SRIF receptor subtypes was also studied by RT-PCR. The results showed that MtT/SGL cells intrinsically expressed the functional GHRH receptor and all of the SRIF receptor subtypes. The expression of GHRH receptor was markedly enhanced by glucocorticoid pretreatment and, in the presence of corticosterone and 3-isobutyl-1-methylxanthine, GHRH (at or above $100 \mathrm{pM}$ ) stimulated GH gene 5'-promoter activity in a dose-dependent manner. On the other hand, SRIF $(100 \mathrm{nM})$ significantly antagonized the effect of $\mathrm{GHRH}$, which was completely reversed by pretreatment with pertussis toxin $(50 \mathrm{ng} / \mathrm{ml})$. Taken together, the present data indicated that both GHRH and SRIF are involved in the transcriptional regulation of the GH gene, and that the effect of SRIF is mediated through pertussis toxin-sensitive $G$ protein. The MtT/SGL cell line is a good in vitro model for studying the molecular mechanisms of GH gene transcription by GHRH and/or SRIF.
\end{abstract}

Journal of Molecular Endocrinology (2003) 31, 441-448

\section{Introduction}

The synthesis and secretion of growth hormone $(\mathrm{GH})$ in the somatotroph of the anterior pituitary are controlled by multiple regulatory factors (Hartman et al. 1993, Harvey 1995, Frohman 1996). Among them, two hypothalamic neuropeptides, GH-releasing hormone $(\mathrm{GHRH})$ and somatostatin (SRIF), are known to be the main regulators of physiological $\mathrm{GH}$ release. GHRH binds to the GHRH receptor (GHRH-R) and increases intracellular cAMP, followed by the activation of protein kinase A (Bilezikjian \& Vale 1983, Mayo 1992). It also causes an increase in intracellular $\mathrm{Ca}^{2+}$, followed by the release of $\mathrm{GH}$ (Rawlings et al. 1991). In contrast, SRIF is shown to suppress GH secretion by reducing intracellular cAMP and/or hyperpolarizing the cells through SRIF receptors (ssts) (Bilezikjian \& Vale 1983, Schettini et al. 1988, Rawlings et al. 1991).

GHRH is known to regulate GH gene expression as well (Barinaga et al. 1983), although the detailed molecular mechanisms have not been clarified completely. In previous studies, $\mathrm{GH}_{3}$ or GC cell lines have been used for studying the transcriptional regulation of the GH gene (Zeytin et al. 1984, Shepard et al. 1994). However, these cell lines do not express intrinsic GHRH-R, and are thus not suitable for studying the regulation of the $\mathrm{GH}$ gene by GHRH.

$\mathrm{MtT} / \mathrm{S}$ is a somatotroph cell line derived from $\mathrm{MtT} / \mathrm{F} 84$ rat pituitary tumor cells. Inoue et al. 
(1990) showed that the cells secrete only GH, not prolactin, and also retain GHRH responsiveness, both of which are characteristics of the pure somatotroph. They also express insulin-like growth factor-I (IGF-I) receptor, and recently we clarified the molecular mechanism of the negative effect of IGF-I on the GH gene 5'-promoter (Niiori-Onishi et al. 1999), which is also observed in the normal somatotroph (Yamashita \& Melmed 1986, 1987).

In this work we have studied the effects of GHRH/SRIF on the $5^{\prime}$-promoter activity of the $\mathrm{GH}$ gene using MtT/S cells. We found that the cell line expresses GHRH-R and all of the subtypes of sst mRNA. Furthermore, our data suggested that SRIF as well as GHRH is involved in the transcriptional regulation of the $\mathrm{GH}$ gene in a positive and negative manner respectively.

\section{Materials and methods}

\section{Materials}

Rat GHRH was a generous gift from Dr S Sawano (Toranomon Hospital, Tokyo, Japan). Somatostatin 14 was purchased from the Peptide Institute (Osaka, Japan). 3-Isobutyl-1-methylxanthine (IBMX), pertussis toxin (PTx) and corticosterone were from Sigma (St Louis, MO, USA).

\section{Cell culture}

MtT/SGL, a subclone of the rat somatotroph cell line $\mathrm{MtT} / \mathrm{S}$ in which the rat $\mathrm{GH}$ gene $5^{\prime}$-promoter $(\approx 1.75 \mathrm{~kb})$-luciferase fusion gene is stably incorporated (Niiori-Onishi et al. 1999), was used in this study. Cells were maintained in a $\mathrm{T}_{75}$ culture flask with Dulbecco's modified Eagles' medium/F12 culture medium (Life Technologies, Grand Islands, NY, USA) supplemented with $10 \%$ horse serum (Sigma), 2.5\% fetal bovine serum (Life Technologies) and antibiotics $(50 \mu \mathrm{U} / \mathrm{ml}$ penicillin and $50 \mu \mathrm{g} / \mathrm{ml}$ streptomycin; Life Technologies) under a $5 \% \mathrm{CO}_{2} / 95 \%$ air atmosphere condition at $37^{\circ} \mathrm{C}$. Culture medium was changed twice a week, and the cells were subcultured once a week.

\section{Experiments}

MtT/SGL cells pretreated with defined dose(s) of corticosterone (see Results) were plated in poly-Dlysine-coated $3.5 \mathrm{~cm}$ diameter culture dishes with approximately $70 \%$ confluence. On the day of each experiment, GHRH or other test reagents, in $1000 \times$ concentration, or solvent alone, were added directly into the culture medium of each dish, and the cells were incubated for the defined timeinterval. Because our preliminary experiments showed that the positive effect of GHRH on the 5 -promoter activity of the GH gene was weak and did not always reach statistical significance, we treated the cells with IBMX $(200 \mu \mathrm{M}$; from $30 \mathrm{~min}$ before the addition of test reagents to the end of the experiment), to obtain consistent responses. At the end of incubation, the culture medium was removed, and the cells were harvested for the determination of luciferase activity. The luciferase assay was performed as previously described (Aoki et al. 1997). IBMX pretreatment did not influence the basal promoter activity of the $\mathrm{GH}$ gene (data not shown). When the cAMP responsiveness to GHRH was to be examined, the MtT/SGL cells were pretreated with corticosterone as above for 3 days, and the culture medium was changed to serum-free medium containing IBMX $(200 \mu \mathrm{M})$. Cells were then incubated with GHRH $(100 \mathrm{nM})$ for $3 \mathrm{~h}$, and the cAMP concentration in the culture medium was estimated by a specific radioimmunoassay (Yamasa Shoyu, Tokyo, Japan).

\section{RT-PCR}

To determine the expression of GHRH-R, total RNAs were isolated from the MtT/SGL cells treated with corticosterone $(1,10$ or $100 \mathrm{nM}$ for 3 days) using RNeasy Mini Kit (Qiagen, Hilden, Germany). One microgram each of the total RNAs was applied for the RT-PGR (30 cycles) using a one-step RNA PCR kit (Takara Shuzo, Ohtsu, Japan), with a specific primer set for the rat GHRH-R mRNA (Takahashi et al. 1995), which amplifies both long and short isoforms of GHRH-R (Mayo 1992, Miller \& Mayo 1999). RT-PCR of the rat glyceraldehyde-3-phosphate dehydrogenase (GAPDH) mRNA with the same RNAs using a specific primer set (Kimura et al. 1998) was carried out as an internal control.

To observe the expression of each subtype of sst mRNA, RT-PCR was carried out as above using $1 \mu \mathrm{g}$ total RNAs, either from MtT/SGL cells treated with corticosterone $(100 \mathrm{nM})$ for 3 days, or from the adult rat whole pituitary gland as a control. Specific primer sets for each subtype of sst 
mRNA were used (Mori et al. 1997), and the cycle number (30 cycles) was determined such that the amplification of GAPDH was submaximal. An RNA sample without reverse transcriptase was also amplified by PCR as a negative control for each reaction. IBMX pretreatment was not carried out in all the RT-PGR experiments.

\section{Data analysis}

Samples in each group of the experiments were in triplicate or quadruplicate. All data are expressed as means \pm S.E. When statistical analyses were performed, data were compared by one-way ANOVA with Fisher's protected least significant difference test using the StatView software for Macintosh (version 4.5; SAS institute, Cary, NC, USA), and $P$ values below 0.05 were considered significant.

\section{Results}

\section{RT-PCR analysis of GHRH-R in MtT/SGL cells}

First, we studied whether MtT/SGL cells have intrinsic GHRH-R using the semi-quantitative RT-PCR technique. As shown in Fig. 1, a single band (564 bp) corresponding to mRNA of the short isoform of the rat GHRH-R was amplified with RNA in corticosterone (100 nM)-treated cells. This band was barely detectable in the cells treated with lower doses of corticosterone, although the amplification of GAPDH used as an internal control was comparable among the groups. We could not detect the long splice variant form of GHRH-R (Mayo 1992, Miller \& Mayo 1999). Similar results were obtained using RNA from $\mathrm{MtT} / \mathrm{S}$ cells (data not shown). No band was amplified from samples in which reverse transcriptase was not added (data not shown). These results showed that MtT/SGL cells express the GHRH-R mRNA, which is enhanced by glucocorticoid treatment.

\section{RT-PCR analyses of sst subtypes in MtT/SGL cells}

We also examined the expression of sst subtypes in MtT/SGL cells using specific sets of primers for each receptor subtype. As shown in Fig. 2, the bands corresponding to sst 1 (270 bp), sst 2 (304 bp), $\mathrm{sst}_{3}$ (286 bp), sst $_{4}(282 \mathrm{bp})$ and $\mathrm{sst}_{5}(274 \mathrm{bp})$ were

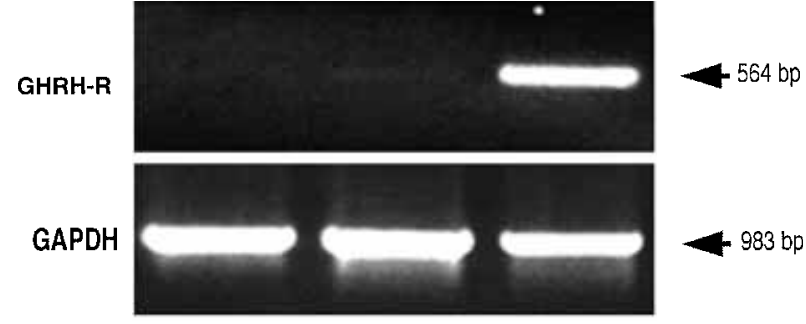

$$
\begin{array}{ccc}
1 & 10 & 100 \\
\hline & \text { corticosterone }(\mathrm{nM})
\end{array}
$$

Figure 1 Expression of the GHRH-R analyzed by RT-PCR in MtT/SGL cells. The figure shows photographs of the ethidium bromide-stained products using agarose gel electrophoresis. cDNA produced from an RT reaction using total RNA from MtT/SGL cells treated with three doses of corticosterone for 3 days was amplified using PCR (30 cycles) with pairs of oligonucleotide primers specific for rat $\mathrm{GHRH}-\mathrm{R}$. A DNA fragment compatible with the short isoform of $\mathrm{GHRH}-\mathrm{R}$ (564 bp) was intensely amplified from the cells treated with $100 \mathrm{nM}$ corticosterone, whereas it was barely detectable in the cells treated with lower doses of corticosterone. The amplification of GAPDH (used as an internal control) was comparable among the groups.

amplified. No band was amplified when samples were treated without reverse transcriptase (data not shown). In the whole pituitary gland used as a control, $\mathrm{sst}_{2}, \mathrm{sst}_{3}$ and $\mathrm{sst}_{5}$ were amplified under the same RT-PCR condition.

\section{Effect of corticosterone pretreatment on GHRH responsiveness of cAMP production}

We then studied the effect of GHRH on cAMP generation in $\mathrm{MtT} / \mathrm{SGL}$ cells pretreated with various doses of corticosterone. As shown in Fig. 3A, GHRH significantly stimulated cAMP efflux into culture medium when the cells were pretreated with corticosterone (100 nM for 3 days), corresponding to the positive effect of corticosterone on GHRH-R expression in Fig. 1. In contrast, no effect of GHRH was observed under low doses of corticosterone $(1-10 \mathrm{nM})$.

\section{Effect of corticosterone pretreatment on GHRH responsiveness of the GH gene 5'-promoter activity}

We also studied the effect of GHRH on the transcriptional activity of the $\mathrm{GH}$ gene in 

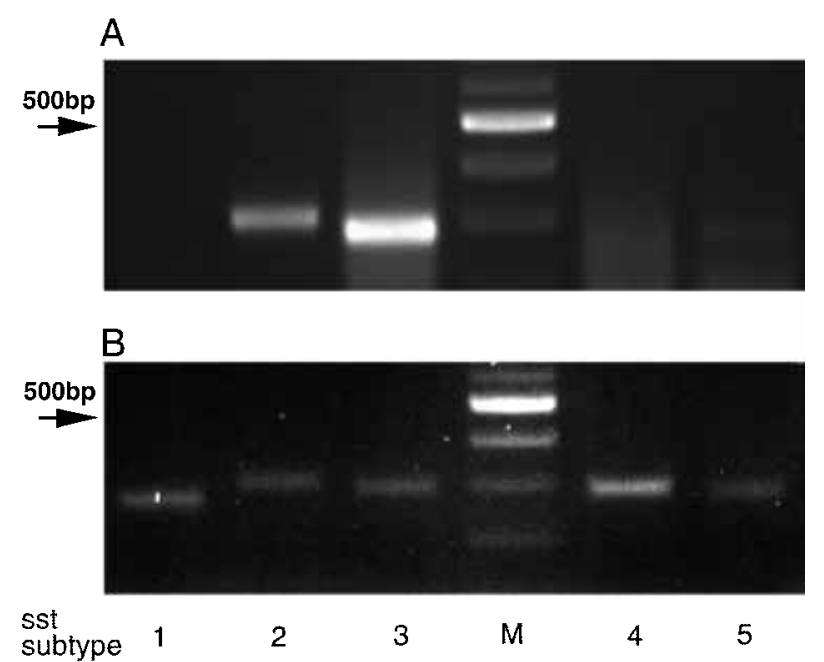

Figure 2 Expression of the sst subtypes analyzed by RT-PCR in the adult rat whole pituitary gland $(A)$ and in MtT/SGL cells (B). The Figure shows photographs of the ethidium bromide-stained products using agarose gel electrophoresis. cDNA produced from an RT reaction using total RNA from either MtT/SGL cells or the rat whole pituitary gland was amplified using PCR (30 cycles) with pairs of oligonucleotide primers specific for each subtype of the rat ssts. DNA fragments with the predicted lengths for $\mathrm{sst}_{2}, \mathrm{sst}_{3}$ and $\mathrm{sst}_{5}$ were amplified from the whole pituitary gland, whereas all the subtypes were amplified from MtT/SGL cells. M, molecular size marker.

MtT/SGL cells pretreated with the three doses of corticosterone. As shown in Fig. 3B, GHRH significantly stimulated the 5 '-promoter activity of the $\mathrm{GH}$ gene when cells were pretreated with corticosterone $(100 \mathrm{nM}$ for 3 days) and IBMX $(200 \mu \mathrm{M}$; from 30 min before the addition of GHRH), again corresponding to the positive effect of corticosterone on GHRH-R expression (data shown above). GHRH had no effect on the cells with low doses of corticosterone (1-10 nM) (Fig. 3A and B) or without pretreatment (data not shown). Subsequent experiments concerning the effect of GHRH on the 5 '-promoter activity of the GH gene were therefore carried out using MtT/SGL cells pretreated with $100 \mathrm{nM}$ corticosterone for 3-4 days.

\section{Time-course and dose-response effects of GHRH on the 5'-promoter activity of the GH gene}

We further characterized the effect of GHRH on the transcriptional regulation of the $\mathrm{GH}$ gene
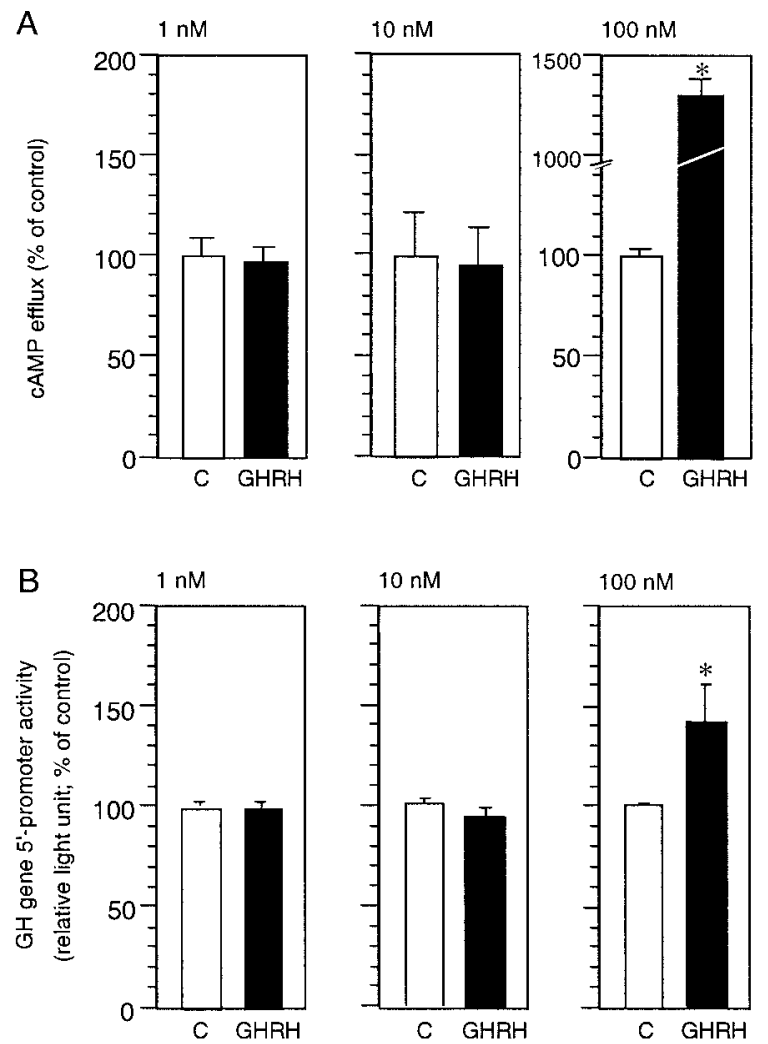

Figure 3 The effect of corticosterone pretreatment on the GHRH responsiveness of cAMP generation and the GH 5'-promoter activity in MtT/SGL cells. (A) Cells were pretreated with 1, 10 or $100 \mathrm{nM}$ of corticosterone for 3 days, and then incubated with GHRH (100 nM) for $3 \mathrm{~h}$ in the presence of IBMX $(200 \mu \mathrm{M}$; from 30 min before the addition of GHRH to the end of the experiment). cAMP efflux into the culture medium was determined by the cAMP assay. (B) Cells were pretreated as above, and then incubated with $\mathrm{GHRH}(100 \mathrm{nM})$ for $8 \mathrm{~h}$ in the presence of IBMX $(200 \mu \mathrm{M})$. Open and closed bars represent the control (C) and GHRH-treated groups respectively. ${ }^{*} P<0.05$ vs control value.

under pretreatment with corticosterone (100 nM for 3 days) and IBMX (200 $\mu \mathrm{M}$; from $30 \mathrm{~min}$ before the addition of GHRH). The time-course study showed that GHRH (100 nM) stimulated the GH gene 5 -promoter activity in a time-related manner (Fig. 4A). A significant effect occurred at $4 \mathrm{~h}$, and the maximal effect was observed $8 \mathrm{~h}$ after the addition of GHRH, with an approximately twofold increase in the transcriptional activity compared with the value at time zero. The dose-response study also showed that an 8-h treatment with GHRH had a dose-dependent positive effect on $\mathrm{GH} 5$ '-promoter activity; the 
A. time-course

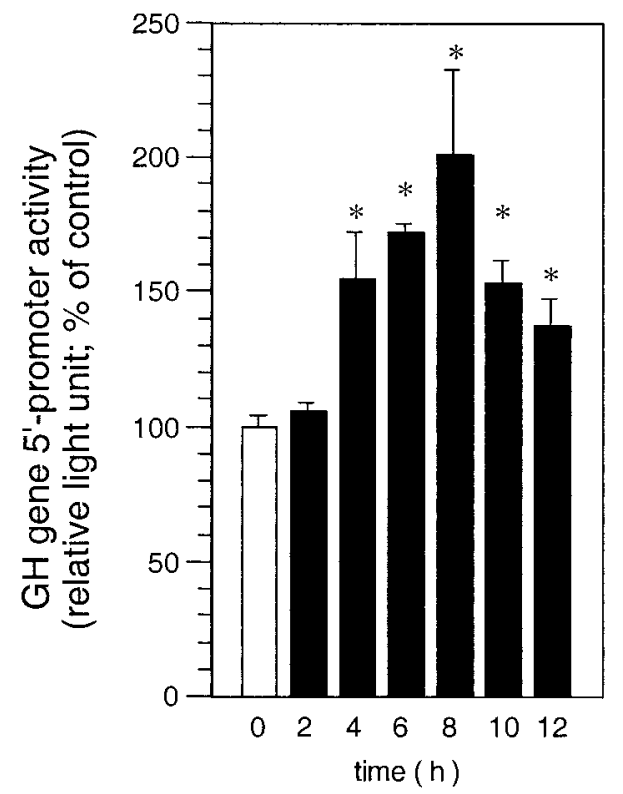

B. dose-response

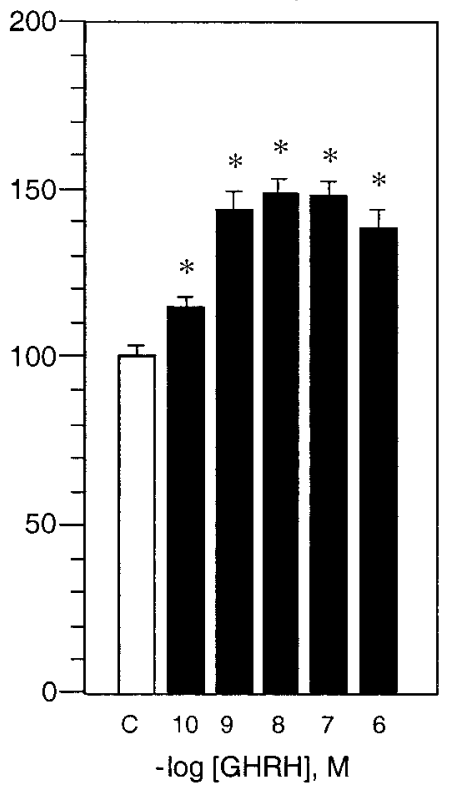

Figure 4 The effects of GHRH on the GH 5'-promotor activity in MtT/SGL cells. (A) The time-course effect; cells were incubated with corticosterone $(100 \mathrm{nM})$ for 3 days, and then treated with GHRH $(100 \mathrm{nM})$ for $0-12 \mathrm{~h}$ in the presence of IBMX $(200 \mu \mathrm{M}$; from $30 \mathrm{~min}$ before the addition of $\mathrm{GHRH}$ to the end of experiment). (B) The dose-response effect; cells were pretreated as above, and also with five different doses of GHRH (100 pM to $1 \mu \mathrm{M})$ for $8 \mathrm{~h}$. $\mathrm{C}$, control. ${ }^{\star} P<0.05$ vs control value or value at time zero.

minimal effect was observed at $100 \mathrm{pM}$, and the maximal one at or above $1 \mathrm{nM}$ (Fig. 4B). IBMX alone had no effect on the basal promoter activity of the GH gene (data not shown).

\section{Combined effects of GHRH and SRIF on the 5 -promoter activity of the GH gene}

Finally, we tested the combined effects of GHRH and SRIF on the transcriptional activity of the GH gene. GHRH alone $(100 \mathrm{nM})$ again significantly stimulated the GH 5'-promoter activity. The addition of SRIF (100 nM), however, partially but significantly suppressed the GHRH-induced transcriptional activity of the GH gene (Fig. 5A), despite the fact that there was no effect with SRIF alone (data not shown). This inhibition was eliminated when the same experiment was carried out under the treatment with PTx (from $8 \mathrm{~h}$ before GHRH/SRIF treatment to the end of the experiment), suggesting that SRIF exerts its negative effect through PTx-sensitive G protein.

\section{Discussion}

We have studied here the effect of GHRH and/or SRIF on the GH gene using the pure somatotroph cell line MtT/S. We have confirmed that GHRH stimulates the $5^{\prime}$-promoter activity of the gene. Furthermore, we found that SRIF is involved in the regulation of the $\mathrm{GH}$ gene in such a way that the hormone interferes with the effect of GHRH through PTx-sensitive G protein.

The transcriptional regulation of the $\mathrm{GH}$ gene has been examined in previous studies using $\mathrm{GH}_{3}$, $\mathrm{GC}$ or $\mathrm{GH}_{4} \mathrm{C}_{1}$ cells (Lefevre et al. 1987, Brent et al. 1989). The $\mathrm{GH}_{3}$ and $\mathrm{GC}$ cell lines, however, are somatomammotrophs which express both $\mathrm{GH}$ and prolactin, the $\mathrm{GH}_{4} \mathrm{C}_{1}$ cells being a mammotroph which secretes only prolactin, and thus all of them may be different from the pure somatotroph in nature. Moreover, neither $\mathrm{GH}_{3}$ nor GG cells possess GHRH responsiveness, implying that they are not suitable for the examination of the physiological effect of GHRH (Chen et al. 1998, 

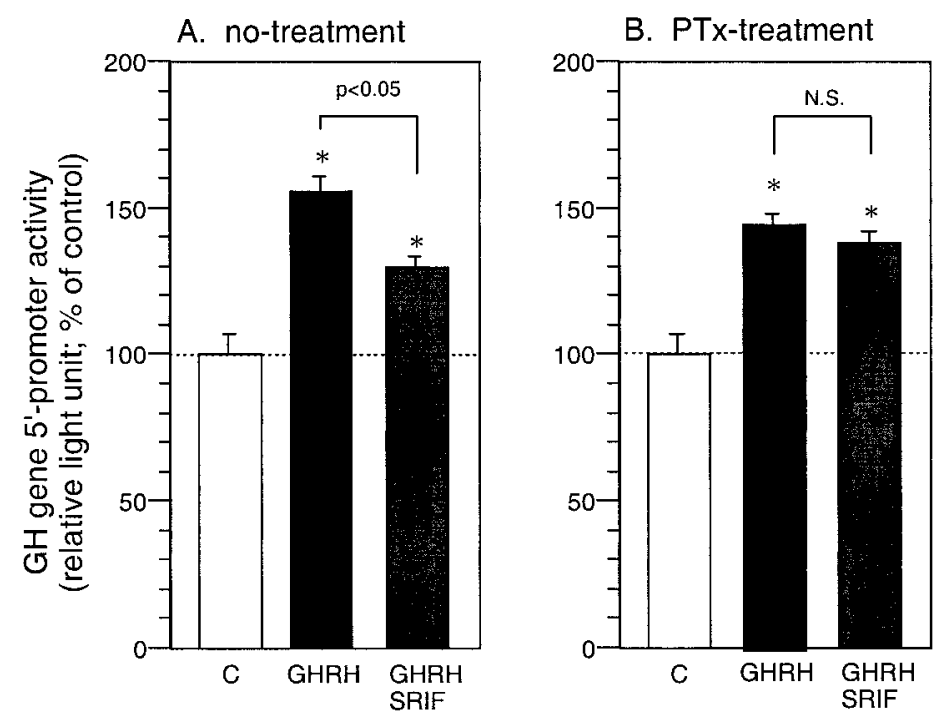

Figure 5 The combined effects of GHRH and SRIF on the GH 5 '-promoter activity in MtT/SGL cells. (A) Cells were pretreated with corticosterone $(100 \mathrm{nM})$ for 4 days, and then treated with GHRH $(100 \mathrm{nM})$ alone, or GHRH and SRIF $(100 \mathrm{nM})$ for $8 \mathrm{~h}$ in the presence of IBMX $(200 \mu \mathrm{M}$; from 30 min before the addition of GHRH to the end of experiment). (B) Cells were pretreated as (A) and also with PTx $(50 \mathrm{ng} / \mathrm{ml}$; from $8 \mathrm{~h}$ before the addition of GHRH/SRIF to the end of experiment). The cells were then treated in the same manner as in (A). C, control. ${ }^{*} P<0.05$ vs control value.

Lee et al. 2001). The MtT/S cell line, in contrast, has been shown to express $\mathrm{GH}$ alone, not prolactin, and it maintains GHRH responsiveness (Inoue et al. 1990). Expression of GHRH-R mRNA in MtT/S cells has already been reported (Nogami et al. 1999, Voss et al. 2001), and we also confirmed the expression of all of the subtypes of ssts. Altogether, $\mathrm{MtT} / \mathrm{S}$ seems to be an appropriate homologous cell line for studying the transcriptional regulation of the GH gene by GHRH and/or SRIF.

GHRH is shown to play a pivotal role in the regulation of $\mathrm{GH}$ gene expression in both in vivo and in vitro systems (Hartman et al. 1993, Harvey 1995, Frohman 1996). In this study, we clearly showed the positive effect of GHRH on the transcription of the $\mathrm{GH}$ gene. Furthermore, the effect was dose-dependent, and occurred at physiological concentrations such as $100 \mathrm{pM}$ GHRH in the hypophyseal portal vein. GHRH stimulation on the amount of GH mRNA or its promoter activity has been demonstrated previously using primary culture, somatomammotroph $\mathrm{GH}_{3}$ or non-endocrine GV1/F9 cell lines (Barinaga et al. 1983, Gohen et al. 1999). We have also confirmed the positive effect of GHRH on GH gene transcription through intrinsic GHRH-R in the pure somatotroph cell line $\mathrm{MtT} / \mathrm{S}$. The increment in the promoter activity, however, was at most approximately twofold even in the presence of IBMX in this cell line, which appears to be the reason why the effect was detectable not by the changes in the amount of GH mRNA (Voss et al. 2001) but by a sensitive reporter gene assay which reflects the de novo changes in the $5^{\prime}$-promoter activity of the $\mathrm{GH}$ gene.

It is of interest that the GHRH responsiveness was glucocorticoid dependent; the effect was recognized only after the cells were treated with $100 \mathrm{nM}$ corticosterone, a physiological rat glucocorticoid, for 3 or more days. This treatment caused both the expression of GHRH-R and cAMP responsiveness to GHRH, suggesting that the restoration of GHRH responsiveness is mediated, at least in part, through the increment in functional GHRH-R. The positive effect of glucocorticoid on GHRH-R has been shown in both in vitro and in vivo studies (Tamaki et al. 1996, Miller \& Mayo 1997), and also in MtT/S cells 
(Miller et al. 1999, Nogami et al. 1999). In addition, Miller et al. (1999) showed that long and short isoforms of GHRH-R mRNA are expressed in $\mathrm{MtT} / \mathrm{S}$ cells. They also found that the bio-inactive long isoform is dominant in the cells with an adhesive nature, a subpopulation of the cells in culture. However, RT-PCR analysis showed that only the bioactive short form of the receptor was amplified in both the MtT/S and MtT/SGL cell lines used in this study, and thus the cell line is thought to possess the potency to respond to GHRH through bioactive GHRH-R. The reason why our cells did not express the long isoform is currently unknown, but was possibly due to the clonal difference of the cell line.

We also examined the effect of SRIF on the transcriptional activity of the $\mathrm{GH}$ gene in this study. Previous works have shown that SRIF is involved in the regulation of GH secretion, but not of GH gene expression (Barinaga et al. 1985). More recent work in vivo, however, has shown controversial data, maintaining the debate on this issue (Sugihara et al. 1993). Our data presented in this paper clearly showed that SRIF partly but significantly suppressed GHRH-induced GH gene transcription, although SRIF alone did not influence the basal promoter activity. Furthermore, the negative effect was completely eliminated by pretreatment with PTx, an inhibitor of suppressive G protein $\left(G_{i}\right.$ or $\left.G_{o}\right)$. Thus, SRIF is involved in the regulation of $\mathrm{GH}$ gene transcription as well as $\mathrm{GH}$ secretion, by interfering with the positive effect of GHRH. This effect seems to be mediated through some subtype(s) of sst, because RT-PCR analysis showed the expression of all of the sst subtypes $\left(\mathrm{sst}_{1}-\mathrm{sst}_{5}\right)$ in this cell line, which includes the dominant subtypes ( $\mathrm{sst}_{2}$ and $\mathrm{sst}_{5}$ ) expressed in the normal somatotroph in vivo (O'Carroll \& Krempels 1995). We hypothesize that SRIF inhibits the GH gene at the adenylate cyclase level through sst(s) and inhibitory G protein (Bilezikjian \& Vale 1983). Alternatively, SRIF exerts its effect downstream of cAMP by inhibiting the non-selective cation channel or calcium channel through G protein/ potassium channel-mediated hyperpolarization, which has been shown in somatotroph cells (Chen et al. 1994). The issue is currently under investigation in our laboratory.

In conclusion, the present data suggest that both GHRH and SRIF play an important role in the transcriptional regulation of the $\mathrm{GH}$ gene. Taken together with our previous data (Niiori-Onishi et al. 1999), we assume that hypothalamic SRIF exerts an acute inhibitory effect by eliminating GHRH stimulation, and IGF-I exerts a chronic inhibitory effect through a long negative feedback loop. Further studies using our homologous MtT/SGL cell line will clarify the intracellular cross-talk among the second messenger systems linked with GHRH/SRIF/IGF-I.

\section{Acknowledgements}

We are indebted to Dr Shinji Sawano for the generous gift of rat GHRH. This work was supported in part by a research grant from the Foundation for Growth Science, Tokyo, Japan.

\section{References}

Aoki Y, Iwasaki Y, Katahira M, Oiso Y \& Saito H 1997 Regulation of the rat proopiomelanocortin gene expression in AtT-20 cells. I: Effects of the common secretagogues. Endocrinology 138 1923-1929.

Barinaga M, Yamonoto G, Rivier C, Vale W, Evans R \& Rosenfeld MG 1983 Transcriptional regulation of growth hormone gene expression by growth hormone-releasing factor. Nature 306 84-85.

Barinaga M, Bilezikjian LM, Vale WW, Rosenfeld MG \& Evans RM 1985 Independent effects of growth hormone releasing factor on growth hormone release and gene transcription. Nature $\mathbf{3 1 4}$ 279-281.

Bilezikjian LM \& Vale WW 1983 Stimulation of adenosine $3^{\prime}, 5^{\prime}$-monophosphate production by growth hormone-releasing factor and its inhibition by somatostatin in anterior pituitary cells in vitro. Endocrinology 113 1726-1731.

Brent GA, Larsen PR, Harney JW, Koenig RJ \& Moore DD 1989 Functional characterization of the rat growth hormone promoter elements required for induction by thyroid hormone with and without a co-transfected beta type thyroid hormone receptor. Fournal of Biological Chemistry 264 178-182.

Chen C, Vincent JD \& Clarke ID 1994 Ion channels and the signal transduction pathways in the regulation of growth hormone secretion. Trends in Endocrinology and Metabolism 5 227-233.

Chen C, Farnworth P, Petersenn S, Musgrave I, Canny BJ \& Clarke IJ 1998 Growth hormone-releasing peptide-2 (GHRP-2) does not act via the human growth hormone-releasing factor receptor in GC cells. Endocrine 9 71-77.

Cohen LE, Hashimoto Y, Zanger K, Wondisford F \& Radovick S 1999 CREB-independent regulation by CBP is a novel mechanism of human growth hormone gene expression. Fournal of Clinical Investigation 104 1123-1128.

Frohman LA 1996 New insights into the regulation of somatotrope function using genetic and transgenic models. Metabolism $\mathbf{4 5}$ (Suppl) 1-3.

Hartman ML, Veldhuis JD \& Thorner MO 1993 Normal control of growth hormone secretion. Hormone Research $4037-47$.

Harvey S 1995 Growth hormone release: integrative hypothalamic control. In Growth Hormone, pp 131-162. Eds S Harvey, CG Scanes \& WH Daughaday. Florida: CRC Press. 
Inoue K, Hattori M, Sakai T, Inukai S, Fujimoto N \& Ito A 1990 Establishment of a series of pituitary clonal cell lines differing in morphology, hormone secretion, and response to estrogen. Endocrinology 126 2313-2320.

Kimura N, Tomizawa S, Arai KN \& Kimura N 1998 Chronic treatment with estrogen up-regulates expression of sst2 messenger ribonucleic acid (mRNA) but down-regulates expression of sst5 mRNA in rat pituitaries. Endocrinology 1391 573-580.

Lee EJ, Duan WR, Kotlar T \& Jameson JL 2001 Restoration of growth hormone-releasing hormone $(\mathrm{GHRH})$ responsiveness in pituitary GH3 cells by adenovirus-directed expression of the human GHRH receptor. Endocrinology 142 414-420.

Lefevre C, Imagawa M, Dana S, Grindlay J, Bodner M \& Karin M 1987 Tissue-specific expression of the human growth hormone gene is conferred in part by the binding of a specific trans-acting factor. EMBO fournal 6 971-981.

Mayo KE 1992 Molecular cloning and expression of a pituitaryspecific receptor for growth hormone-releasing hormone. Molecular Endocrinology 6 1734-1744.

Miller TL \& Mayo KE 1997 Glucocorticoids regulate pituitary growth hormone-releasing hormone receptor messenger ribonucleic acid expression. Endocrinology 138 2458-2465.

Miller TL, Godfrey PA, Dealmeida VI \& Mayo KE 1999 The rat growth hormone-releasing hormone receptor gene: structure, regulation, and generation of receptor isoforms with different signaling properties. Endocrinology 140 4152-4165.

Mori M, Aihara M \& Shimizu T 1997 Differential expression of somatostatin receptors in the rat eye: SSTR4 is intensely expressed in the iris/ciliary body. Neuroscience Letters 223 185-188.

Niiori-Onishi A, Iwasaki Y, Mutsuga N, Oiso Y, Inoue K \& Saito H 1999 Molecular mechanisms of the negative effect of insulin-like growth factor-I on growth hormone gene expression in $\mathrm{MtT} / \mathrm{S}$ somatotroph cells. Endocrinology $140344-349$.

Nogami H, Inoue K, Moriya H, Ishida A, Kobayashi S, Hisano S, Katayama M \& Kawamura K 1999 Regulation of growth hormone-releasing hormone receptor messenger ribonucleic acid expression by glucocorticoids in $\mathrm{MtT} / \mathrm{S}$ cells and in the pituitary gland of fetal rats. Endocrinology 140 2763-2770.

O'Carroll AM \& Krempels K 1995 Widespread distribution of somatostatin receptor messenger ribonucleic acids in rat pituitary. Endocrinology $1365224-5227$.

Rawlings SR, Hoyland J \& Mason WT 1991 Calcium homeostasis in bovine somatotrophs: calcium oscillations and calcium regulation by growth hormone-releasing hormone and somatostatin. Cell Calcium 12 403-414.

Schettini G, Florio T, Meucci O, Landolfi E, Lombardi G \& Marino A 1988 Somatostatin inhibition of anterior pituitary adenylate cyclase activity: different sensitivity between male and female rats. Brain Research 439 322-329.

Shepard AR, Zhang W \& Eberhardt NL 1994 Two CGTCA motifs and a GHF1/Pitl binding site mediate cAMP-dependent protein kinase A regulation of human growth hormone gene expression in rat anterior pituitary GC cells. Fournal of Biological Chemistry 269 1804-1814.

Sugihara H, Minami S, Okada K, Kamegai J, Hasegawa O \& Wakabayashi I 1993 Somatostatin reduces transcription of the growth hormone gene in rats. Endocrinology 132 1225-1229.

Takahashi T, Okimura Y, Yoshimura K, Shigeyoshi Y, Kaji H, Abe H \& Chihara K 1995 Regional distribution of growth hormone-releasing hormone $(\mathrm{GHRH})$ receptor mRNA in the rat brain. Endocrinology $1364721-4724$.

Tamaki M, Sato M, Matsubara S, Wada Y \& Takahara J 1996 Dexamethasone increases growth hormone $(\mathrm{GH})$-releasing hormone $(\mathrm{GHRH})$ receptor mRNA levels in cultured rat anterior pituitary cells. Fournal of Neuroendocrinology 8 475-480.

Voss TC, Goldman LR, Seek SL, Miller TL, Mayo KE, Somogyvari-Vigh A, Arimura A \& Hurley DL 2001 GH mRNA levels are elevated by forskolin but not $\mathrm{GH}$ releasing hormone in GHRH receptor-expressing MtT/S somatotroph cell line. Molecular and Cellular Endocrinology 172 125-134.

Yamashita S \& Melmed S 1986 Insulin-like growth factor I action on rat anterior pituitary cells: suppression of growth hormone secretion and messenger ribonucleic acid levels. Endocrinology 118 176-182.

Yamashita S \& Melmed S 1987 Insulin like growth factor I regulation of growth hormone gene transcription in primary rat pituitary cells. Fournal of Clinical Investigation $79449-452$.

Zeytin FN, Gick GG, Brazeau P, Ling N, McLaughlin M \& Bancroft C 1984 Growth hormone $(\mathrm{GH})$-releasing factor does not regulate $\mathrm{GH}$ release or $\mathrm{GH}$ mRNA levels in $\mathrm{GH}_{3}$ cells. Endocrinology 114 2054-2059.

\section{Received 27 July 2003}

Accepted 15 September 2003 